Fiedorczuk J. (2015). Sustainable Development in Norway on the example of Government Pension Fund Global. Copernican Journal of Finance \& Accounting, 4(1), 45-54. http://dx.doi. org/10.12775/CJFA.2015.003

\author{
JuLita Fiedorczuk* \\ The Faculty of Economics and Management, University of Bialystok
}

\title{
SUSTAINABLE DEVELOPMENT IN NORWAY \\ ON THE EXAMPLE OF GOVERNMENT PENSION FUND GLOBAL
}

Keywords: sustainable development, Global Government Pension Fund, Norway.

J E L Classification: F39, G23, G32, H61, I31, 011, 013, 016, 021, 023, 044, Q01.

\begin{abstract}
This article is an attempt to assess the functioning of the Norwegian Government Pension Fund Global in relation to the degree of implementation of the concept's objectives of sustainable development. The aim of the article apart from this assessment is to determine significance and the benefits of the concept to the Fund and the country. To apply the hypothetical-deductive method. The concept of sustainable development has a relatively long history in Norway. Sustainable development is not just a dead regulation, but a way of thinking Norwegians. Social awareness of balance need causes of naturalness of reconciling the economic, social and environmental interest in economy. On the one hand, Fund acting within state structures, is the implementing tool of sustainable development policy. On the other, the Fund uses assumptions of the concept to achieve sustainable economic benefits. Maturity sustainable activities of the Fund contributes to the achievement of competitive advantage among other funds. The Fund is the largest Government Pension Fund in the world in terms of net assets, of which the largest part of the market value is an inflow of capital from outside. Investors deposit their funds in it because they trust to management style. Due to the global character, size and geographical or investment diversification, manifestation of sustainable practices reaches to wide-spectrum of recipients. The range of message builds
\end{abstract}

Date of submission: January 9, 2015; date of acceptance: February 20, 2015.

* Contact information: fiedorczukjulita@uwb.edu.pl, The Faculty of Economics and Management, University of Bialystok, Warszawska 63, 15-062 Bialystok, Poland, phone: 0857457716 . 
the Fund and country reputation that actively suggests the only one way to sustainable development.

Translated by Julita Fiedorczuk

\section{IIINTRODUCTION}

Implementing the concept of sustainable development is the only possible way to the stable satisfy economic-social needs of the world while avoiding environmental degradation. Due to the fact that the decisive role in the implementation of the concept is attributed to governance ${ }^{1}$, the most sustainable economies has large state involvement in the market and the welfare state status. One of them is Norway, where all of polities and activities are subordinated by the concept of sustainable development. Also, the equality and fight against disproportions are the stimuli to create Government Pension Fund. Fund as a state institution is Norway's image of management style and as the largest government investment fund in the world is an effective communicator informing about the importance of applying the concept of SD.

\section{THE RESEARCH METHODOLOGY AND THE COURSE OF THE RESEARCH PROCESS}

To investigate undertaken problem has been used the hypothetical-deductive method. It is assumed that the GPFG is an active performer and promoter of the concept of sustainable development. In addition, it is believed that the profound realization of the concept of sustainable development is a tool to build competitive advantage of Fund and Norway. The assess the implementation of the concept will be based on internal Fund reports ${ }^{2}$. Conclusions derived from them have been confronted with the results of the international organizations and the available literature. Due to the small number of differences in the ideology of CSR and SD at the level of assumed them to be identical ${ }^{3}$.

${ }^{1}$ Due to RobecoSAM's Country Sustainability Ranking 2013 60\% of Sustainability Factors is the governance dimension.

2 The GPFG is one of the most transparent fund in the world (SWFI 2014; Behrendt $2010,6)$ and received one of the Truman Oil solvents resistance rating of SWF Scoreboard. (Truman 2007, 15) It publishes and complete lists of its holdings as well as its voting records in its quarterly and annual report. The GPFG publishes the benchmark portfolios used to measure its performance against.

3 The concept of sustainable development and CSR have more common characteristics than differences. Clearest ideological differences are: the level of implementation 


\section{SELECTED ASPECTS OF SUSTAINABLE DEVELOPMENT IN ECONOMIC THEORY}

The beginning of the concept of sustainable development is considered to the Second Session of the Executive of the United Nations Environment Programme in 1975. The next step was to propose the idea of sustainable development set out in the report of the World Commission on Brundlandt'a United Nations Environment and Development Programmes in 1987. Sustainable development on the basis of the Report Brundlandt (Report 1987, 41) was defined as: „,the development, that meets the needs of the present, without compromising the ability to meet the needs of future generations. It is based on two concepts: needs - in particular the essential needs of the poorest in the world, which should be given the highest priority, and limitations - imposed capacity of the environment to meet the needs of present and future by the state of technology and social organization."

Satisfaction with life was equated with economic growth. For this reason, the economic growth was considered to be the most important economic objective. This view has been changed since the 70s. In parallel with the increase in interest in the sustainability has been growing popularity of the concept of quality of life. This term goes above and beyond economics, as determined multifaceted human satisfaction, which has to be tested through tangible and intangible indicators (Kiełczewski 2009, 109). This does not mean that the economic component of sustainable development is not significant. The guidelines of sustainable development assume that it can not be the most important. The dominance of each group of purposes is inappropriate (Ślężyński 2007, 9).

The importance of the state in achieving and maintaining a sustainable balance between the environment, human and economic prosperity is very fundamental. The market is very efficient allocation mechanism in the event of a short term, but is not able to protect the hand of the invisible nature and human satisfaction. Only the state is able to effectively manage the free goods and represent the interests of the whole community in the long term. (Chmielak 2002, 80-82)

The idea of sustainable development is a relatively new global style of thinking pointing the way to achieve sustainable development. The main purpose of the development model based on its assumptions is to maintain a balance be-

of the concept (CSR - scale micro SD - the whole globe, country), the origin of creation (Jonker, Reichel, Rudnicka 2011, 41-42) and the expected time horizon (usually a long period of planning and implementation occurs in the case of sustainable development). 
tween people, nature and prosperity on a global scale. In the face of globalization of economies is a growing awareness that the problem of poverty, environmental hazards or food does not end within the borders of the countries concerned. Expanding development perspective, he sees more and more clearly the needs of the future generations.

\section{SuSTAINABLE DEVELOPMENT IN NORWAY}

Norway has been actively advocate of concept of sustainability since the pasts decades. Norway effectively implements and promotes the principle of balance between the main elements of sustainable development. Social sensitivity, widely understood egalitarianism, a sense of social justice and respect for nature can not be actualized only in a utopian model. The Norwegian compromise is a result of many causes: religion, culture, historical circumstances, their policies and the social mood of the Norwegian society. In the ranking of the World Economic Forum in 2005 in terms of sustainable development index Norway took second place (Angel 2013, 22).

The meaning of sustainable development is adopted in Norway in accordance with the definition of the Brundtland Report from 1987. (Indicators $2005,6)$ This definition is used in Norway in all documents related to the theme of sustainable development of the country such: National Action Plan for Sustainable Development (2003), Norway's Strategy for Sustainable Development (2002) and A Peer Review of Norway's Policy for Sustainable Development or even Corporate Social Responsibility in a Global Economy (2009).

Norway is the one of the richest economies in the world. Norway frequently been regarded as the state with the highest level of socio-economic development according to the United Nations Development Programme. The country of fjords in terms of quality of life was already the leader of twelve times. Norway's HDI was 0.955 in 2012, placing it at first place again, among the other economies (International 2014). Norway achieved result of GDP per capita about $86 \%$ higher than the average members of the European Union in 2011 and 18\% higher than Switzerland, which was the next place in Norway at this time (GDP 2011).

Norway is one of the first countries in the world that has established in 2009 the state document about the standards of conduct relating to Corporate Social Responsibility. (Corporate 2014). It is not surprising that the list of the 100 most sustainable corporations of 2012, the top ten were two Norwegian state companies (Statoil and Norsk Hydro) (Angel 2013, 19). 
Manifestation of sustainable development within the social pillar can be generalized to create for the residents the conditions of a sense of security, happiness and equality. A Scandinavian model creates the ability to implement this concept. This model consists of the mechanism of the welfare state, nordic economic policy and political and economic system. Solutions of Scandinavian model would have not achieved without the approval of Nordic society, which largely bear the cost of sustainable economy. In Norway even the state intervention crystallized naturally, giving a solid foundation for the so-called. "Happy democracy", which similarly to sustainable development, is a political consensus, economic and social (Nowiak 2011, 72-77).

Norway is a country maintaining very high environmental standards. They are part of the national legal order. Both the state and society treats nature as a national heritage. The environmental aspect in Norway gained strategic importance even before the official creation of the concept of sustainable development. In 1972, Norway was the first country in the world has created an unit Ministerial dealing with issues of responsibility for the environment. (Report No. 14, 2007) The need for the establishment of units is result of the culture and Nordic tradition, whose main purpose is to manage the entire planet so that future generations can enjoy the unchanged nature (Harrison 2003, 70, 74).

The confirmation of the effectiveness of Norwegian policies is fifth position sustainable country (RebecoSAM 2013, 6) and eighth place in the world in terms of the development of the so-called green economy. Exemplification of what is the Global Green Economy Index from 2012 developed by the Dual Citizen (Copenhagen 2013). Norway has attained a such high results of this kind of rankings in this regard by the economic system - a combination of market economy and state intervention. Pure market mechanism is not able to implement the principles of social justice. Difficulty in being self-sufficient and independent in such hard conditions, resulted in understanding the meaning of the state and institutions, which can move on some part of the responsibility and risks of satisfy all the needs of society. From the same reason society fully accept applied redistribution of income and participates in the costs for the selfmade construction of sense of security.

Sustainable development in Norway is poured out on all areas of activity. On the basis of the Scandinavian economy sustainable action are very mature, because its origins are much earlier than the beginning of concept of sustainable development. Approval for sustainability follows from previous experiences of this nation. Norwegians believe in effectiveness of counterbalance (economy- 
human-nature), which does not reduce economic welfare in long term. Sustainable initiatives are supported by the legal system, state funds devoted to their implementation and society in Norway.

\section{Sustainable development in Government Pension Fund}

From the practice point of view ${ }^{4}$ Government Pension Fund Global is a tool for ensuring sustainable development in Norway and promoting it in the world. The main reason for its creation is the idea of a fair distribution of wealth between generations, resulting from the scarcity of natural resources, the illusion resembling a definition of the concept. After the exhaustion of raw materials, accumulated capital can be used to finance pension obligations or be better used to mitigate the effects of the decline in budget revenues.

Government Pension Fund of the biggest Government Sovereign Fund in terms of accumulated assets in the world (Sovereign 2013). In the last decade have noted a huge increase in the importance of investment funds in the financial markets and their role in the global economy (Review of Finance 2013, 483).

The concept of sustainable development at the level of the organization is poorly defined and represents a new approach in the management sciences (Adamczyk 2001, 32). The transformation of English literature from the sustainable development concept from macro and micro level is defined as a sustainable business (Paliwoda-Matiolańska 2014, 246), a corporation which is based on sustainable development (sustainable corporation). According to the definition of this term is given by Banerjee is an organization that strives to increase the economic long-term value for shareholders, through the integration of economic, environmental and social opportunities to increase the value of corporate strategy (Baberjee 2002, 107). In this sense, sustainable organizations can easily discern the four dimensions of socially responsible organization, proposed by Duahlsrud (without exposed dimension of volontariness). This causes difficulty in making a clear distinction between the activities falling under the implementation of the concept of corporate social responsibility and sustainable development at the level of the organization, which the Fund is.

GPFG is becoming more resilient executor of the concept of SD and CSR ESG principles. The Fund is active ownership bases on the UN Global Compact, the

${ }^{4}$ From the practice point of view, because the Ministry of Finance issued press release standing that "GPFG is financial investor, no policy tool". 
OECD's Principles of Corporate Governance and the OECD Guidelines for Multinational's Enterprises. On the basis of internal documents ${ }^{5}$ and scientific articles defining and regulating the operation of the fund can be concluded that sustainable balance is well-established legislative part of the management. The foundation for achieving the objectives of the concept has already created organizational structure, which provides a secure changes and reciprocal control between authorities. Advisory bodies and public consultations shall support the important decisions. Priority the principles of ethical and responsible investing emphasizes by existence of independent, specially established cells The Council on Ethics. The Council makes public exclusion from the portfolio of investors who violate the security of investments by engaging in activities condemned (corruption, the production of weapons, violations of human and children rights, actions detrimental to the environment) by the Fund. Long-term planning perspective is the way to achieve the main goal - integration of ethical and financial cell. The Fund resigns of short-term profits, incurs expenses, but gaining the reputation and investors trust. The market value of the fund from 2013 years accounted for over $60 \%$ of the inflow of capital from outside (Government 2014). The expenditures for concept realization are same kind of advertising costs. Status responsible global investor increases the sense of security, the market value of their assets, and thus the range of information confirming the effectiveness of the Norwegian state-owned assets management style. This result seems to be strong than multiplying the expected accumulated capital. Having experience can become a competitive advantage.

The results of WWF Report from 2008 year, indicate that there are many reasons to Norwegian government naturally played a leading role in the future global investing (Innovest 2008, 70-71). Performing this function would be to being an active representative government funding and integration of tools in the government responsible investing pension funds in order to change the world economy in a more socially and environmentally sustainable. Oslo is indicated as potentially the world capital of socially responsible investing, due to the current consistency and naturalness responsible activities.

International organizations hierarchizing Sovereign Pension Funds deem GPFG as a leader in the implementation of the concept of SD. Operation of the Fund supporting sustainable development are assessed more strictly. Fund

5 The Invest strategy, the Guidelines of Ethics, Norwegian Ministry of Finance, Internal Report to the Storing (2006, 2007, 2008, 2009, 2010, 2011, 2012,2013, 2014) and Mandates GPFG, Other reports. 
prompts suggestions of these organizations and improves areas identified in these analyzes. In 2008, in terms of the sustainability of improved environmental dimension in response to the WWF report, which indicated insufficient fund involvement in activities against climate changes. After stabilization of the economy after the financial crisis Yngve Slyngstad (2013) increased the share of investment in environmentally friendly companies to $1 \%$ of the assets, and from 2015 Investement push into renewable energy, water management and energy-storage companies. After the report, UNEP Finance Initiative and United Nation Global Compact on the transparency of the Ministry of Finance is considering the use of a new reporting tool called screening possitive.

\section{THE CONCLUSIONS}

The Fund is a transnational institution which facilitates outgoing initiatives outside the country. This activities rely on using of sustainable development practices, sending signals about the necessity of their application by potential, current investors and observers. Compliance with the ethical rules is necessary to start co-operation with the Fund. The Fund activity is example of sustainable practices, making the management model of state wealth in the face of current limitations and future needs. The Fund is a resilient executor and promoter of sustainable development concept. Sustainable activities are very mature. When evaluating sustainable development, it is necessary to establish the Norwegian model because it creates the possibility to implement this concept in a very natural way. Social attitudes of equality and justice enhance awareness of the need for and importance of CSR and SD by society and the State. These factors make the use of the concept of CSR is in Norway direction of the government's actions to improve its competitiveness in the long run. In summary, the main purpose of the article have been achieved. The concept of sustainable development is permanent way to stay competitive investor in the world.

\section{REFERENCES}

Adamczyk J. (2001), Koncepcja zrównoważonego rozwoju w zarządzaniu przedsiębiorstwem, Akademia w Krakowie, Kraków.

Anioł W. (2013), Szlak Norden. Modernizacja po skandynawsku, Elipsa, Warszawa.

Baberjee S. B. (2002). Organizational strategies for sustainable development. Australian Journal of Managenent, No 27. 
Bachnik K. (2010), Skandynawskie uwarunkowania kulturowe w procesach zarządzania, CeDeWu, Warszawa.

Behrendt S. (2010), Sovereign Wealth Funds and the Santiago Principles, Carnegie Endowment, Washington.

Chmielak A. (2002), Instytucjonalne podstawy trwałości rozwoju gospodarczego, WSFiZ w Białymstoku, Białystok.

Copenhagen Cleantech Cluster, Global Green Economy Index Ranks Denmark, Top, http:// www.cphcleantech.com/global-green-economy-index (accessed: 10.01.2014).

Dahlsrud A. (2008), How corporate social responsibility is defined, Wiley InterScience. 10.1002/csr.132.

Government (2014), Market value, https://www.regjeringen.no/en/topics/the-economy/the-government-pension-fund/government-pension-fund-global-gpfg/marketvalue-and-capital-inflow/id696852/ (accessed: 17.02.2015).

Kiełczewski D. (2009), Jakość życia i dobrobyt jako kategorie zrównoważonego rozwoju, [in:] Od koncepcji ekorozwoju do ekonomii zrównoważonego rozwoju, red. Kiełczewskiego Dariusza, WSE w Białymstoku, Białystok.

Kołodziejczyk H. (2011). Współczesne trendy na światowym rynku finansowym - Sovereign Wealth Funds. Przegląd Prawniczy, Ekonomiczny i Społeczny, 3-4/2011, Poznań.

Jonker J., Reichel J., Rudnicka A. (2011), Nowe horyzonty. Przewodnik po społecznej odpowiedzialności i rozwoju zrównoważonym, Centrum Strategii i Rozwoju Impact, Łódź.

Innovest Strategic Value Advisors for WWF (2008), Fund Management in the 21st Century: The role of sovereign wealth funds in contributing to a low carbon future, http://www.wwf.se/source.php/1215663/Fund\%20Management\%20in\%20 the $\% 2021$ st\%20Century.pdf (accessed 18.02.2015).

Harrison L. E., Huntington L. P. (2003), Kultura ma znaczenie, Wydawnictwo Zysk i S-ka, Poznań.

Miguel A. F., Miguel A. F., Ramos S. (2013), Keswani A., The determinants of mutual Fund Performance, [in:] Review of Finance, Oxford Uniwersity Press, Nr 2/2013, Glasgow.

Ministry of Climate and Environment, Report No. 14 to the Storting (2006-2007), http://www.regjeringen.no/nb/dep/kld/dok/regpubl/stmeld/2006-2007/ReportNo-14-2006-2007-to-the-Storting.html?id=495434 (accessed: 19.0.2014).

Ministry of Finance, Council on Ethics, http://www.regjeringen.no/en/sub/styrer-radutvalg/ethics_council.html?id=434879 (accessed: 13.01 .2014 ).

Ministry of Finance, Indicators for Policies to Enhance Sustainable Development Oslo, March 2005, http://www.regjeringen.no/en/dep/fin/Documents-and-publications/Guidelines-and-brochures/2005/Sustainable-Development-National-Agenda-.html?id=419468 (accessed: 28.01.2014).

Ministry of Foreign Affairs, Corporate Social Responsibility, http://www.regjeringen. no/en/dep/ud/selected-topics/csr_en.html?id=621814 (accessed: 25.01.2014).

Nowiak W. (2011), Nordycki model “welfare state” w realiach XXI wieku, Wydawnictwo Naukowe WNPiD UAM, Poznań. 
Paliwoda-Matiolańska A. (2014), Odpowiedzialność społeczna w procesie zarządzania, Wyd. II, C.H. Beck, Warszawa.

PRI, Signatories to the Principles for Responsible Investment, http://www.unpri.org/ signatories/signatories/?country=Norway (accessed: 17.02.2015).

RobecoSAM (2013), Country Sustainability Ranking 2013, http://www.robecosam. com/images/CS_Ranking_E_Rel.FINAL.pdf (accessed: 16.02.2015).

Rogall H. (2010), Ekonomia zrównoważonego rozwoju. Teoria i praktyka, Wyd. I, Zysk i S-ka, Poznań.

Ślężyński J. (2007), Rola wskaźników realizacji trwałego rozwoju, [in:] Prace naukowe Akademii Ekonomicznej im. Oskara Langego we Wrocławiu, pod red. Graczyka A., Wyd. o AE im. Oskara Langego we Wrocławiu, Wrocław.

Sovereign Wealth Fund Name (2013), SWF Institute, http://www.swfinstitute.org/ fund-rankings/ (accessed: 12.12.2014).

SWFI (2014), Linaburg-Maduell Transparency Index, ://www.swfinstitute.org/statistics-research/linaburg-maduell-transparency-index/ (accessed: 15.02.2015).

Statistics Norway, GDP per capita, price level adjusted, 2009-2011, http://www.ssb.no/ en/priser-og-prisindekser/statistikker/ppp (accessed: 25.02.2015).

The Earth Institute (2012), World Happiness Raport 2012, Columbia University, Columbia.

Truman E. M. (2007), A Scoreboard for Sovereign Wealth Funds, Peterson Institute, Washington.

UNDP, International Human Development Indicators, Countries: Norway, http:// hdrstats.undp.org/en/countries/profiles/NOR.html (accessed: 25.01.2014).

Yermo J. (2008), Governance and Investment of Public Pension Reserve Funds In Selected OECD Countries, ISSN 1995-2864, Financial Market Trend, OECD. 